\title{
The Effects of in vitro Hyperglycemic Incubation on A23187-Mediated Contractile Responses of Rat Thoracic Aorta
}

\author{
In vitro Hiperglisemik Inkübasyonun Sıçan Torasik Aort Preparatında A23187-Aracılı Kontraktil Yanıtları \\ Üzerindeki Etkileri
}

\section{Işı Özakca}

Ankara University, Faculty of Pharmacy, Department of Pharmacology, Ankara, Turkey

\begin{abstract}
Objective: Vascular tonus has been controlled by several factors secreted from endothelium in physiological conditions. In the present study, the possible changes on endothelium-derived contractile responses in normoglycemic and hyperglycemic conditions in terms of exposure-time dependency has been investigated.

Methods: To assess the possible alterations under acute hyperglycemia with different incubation periods on endothelium-derived contractile responses in isolated rat thoracic aorta, A23187-mediated contractile responses were performed in a cumulative manner for isometric tension measurements.

Results: Incubation for 3 hours with Krebs solution containing high glucose increased the A23187-mediated contraction of rat thoracic aorta. The A23187induced contraction significantly decreased in response to the same incubation period with normoglycemic conditions and totally abolished with incubation for 6 hours. The possible effects of osmotic pressure induced by high glucose content checked with mannitol.

Conclusion: Our results indicated that the A23187-mediated contractile response was increased by acute hyperglycemia. These data has shown the detrimental effects of short term hyperglycemia on endothelium-derived contractile factors. Also the incubation period-related characteristics of A23187-mediated contractile responses as observed in normoglycemic conditions indicate the unstable properties of endothelium-derived contractile factors and/or related signaling pathway(s).
\end{abstract}

Key Words: Diabetes mellitus, Vascular smooth muscle, Endothelium, Hyperglycemia, Aging.

Received: 01.31.2018

\begin{abstract}
ÖZET
Amaç: Vasküler tonüs fizyolojik şartlarda endotelden salınan faktörler tarafından kontrol edilmektedir. Çalışmamızda, normoglisemik ve hiperglisemik koşullarda maruziyet süresine bağımlı olarak endotel-kaynaklı kontraktil yanıtlardaki olası değişiklikler incelenmiştir.

Yöntem: İzole sıçan torasik aortunda akut hiperglisemik koşulların farklı inkübasyon sürelerinde endotel-kaynaklı kontraktil yanıtlar üzerinde oluşturdukları olası değişikliklerin değerlendirilmesi için, A23187-aracılı kontraktil yanıtlar izometrik gerim ölçümleri için kümülatif olarak çalışılmıştır. Bulgular: Yüksek glukoz içeren Krebs çözeltisi ile 3 saatlik inkübasyon, sıçan torasik aortunda A23871-aracılı kontraksiyonu arttırmıştır. A23187 ile indüklenen kontraksiyon, normoglisemik koşullarda aynı inkübasyon süresine yanıt olarak anlamlı olarak azalmış, 6 saatlik inkübasyon sonucunda da tümüyle kaybolmuştur. Yüksek glukoz içeriğine bağlı olarak gelişebilecek ozmotik basıncın olası etkileri mannitol ile kontrol edilmiştir.

Sonuç: A23187-aracılı kontraktil yanıtlar akut hiperglisemi ile artmıştır. Sonuçlarımız kısa dönem hipergliseminin endotel-kaynaklı kontraktil faktörler üzerindeki olumsuz etkisini göstermektedir. Normoglisemik koşullarda gözlenen A23187-aracılı kontraktil yanıtların inkübasyon süresi ile ilişkili özellikleri, endotel-kaynaklı kontraktil faktörler ve/veya ilişkili sinyal yolaklarının değişken özelliklerini göstermektedir.
\end{abstract}

Anahtar Sözcükler: Diabetes mellitus, Vasküler düz kas, Endotel, Hiperglisemi, Yaşlanma.

Kabul Tarihi: 06.03.2018 


\section{INTRODUCTION}

Macro- (cardiovascular and cerebrovascular) and micro-vascular (retinopathy, neuropathy and nephropathy) complications are the leading causes of morbidity and mortality in diabetes mellitus (1). Chronic hyperglycemia has been described as the major factor for the development of diabetic complications (2).

The endothelium plays a crucial role in regulating vascular tone and structure. These include maintanence of a non-thrombotic surface and adjustment of vascular tone by endothelium-derived factors. Hyperglycemia impairs endothelial function and directly increases superoxide production by activating the polyol, hexosamine, protein kinase $c$ and pentose phosphate pathways $(1,2)$.

Hyperglycemia induces many changes in vascular homeostasis. One of the hyperglycemia-induced changes is endothelial dysfunction which is characterized with decreased nitric oxide (NO)-dependent vasodilatation (2). Vascular tone is tightly regulated by endothelium-derived relaxation factors (EDRF) such as NO, endothelium-derived hyperpolarization factors (EDHF) and endothelium-derived contractile factors (EDCF) (3). Alterations in these factors can lead to the changes in resting blood pressure. Especially a reduced production of EDRFs and/or impairment in the EDRF signaling pathway can be responsible from the development of increased vascular tonus. In addition to the decreased endothelium-derived relaxation responses, increased EDCF production and/or signaling can be a reason for the development of vascular complications (4).

The release of EDCF can be triggered by vasoactive agonists which interacted with specific receptors located in the cell membrane, such as acetylcholine (5) or ADP (6). The EDCF-mediated contractility can also be evoked by calcium ionophores like A23187 by increasing the cytosolic calcium concentration in a receptor-independent manner $(7,8)$. It is suggested that the increase in cytosolic calcium concentrations mediates activation of phospholipase A2 and arachidonic acid pathway in endothelial cells (9). The cyclooxygenase products which are synthesized from arachidonic acid in the endothelium mediates contraction by activating thromboxane-prostanoid (TP) receptors in vascular smooth muscle (10).

The effect of EDCF can be seen not only in pathologies like hypertension and chronic diabetes in which endothelial dysfunction has been observed but also in conditions like acute hyperglycemia, hypoxia and aging in which the production of reactive oxygen species (ROS) has increased (11). The aim of the present study is to evaluate the possible effects of acute hyperglycemia on A23187-mediated contractile responses in rat thoracic aorta.

\section{METHODS}

Experimental animals

All animal procedures were approved by Institutional Ethical Committee of Ankara University (Approval ID: 2015-10-124). 10- and 34-week-old male Sprague-Dawley rats obtained from Bilkent University Department of Molecular Biology and Genetics (Ankara, Turkey). The rats were housed in individual cages at $22 \pm 1{ }^{\circ} \mathrm{C}$ and 12 -h light/darkness cycle. The rats were fed with standard rat chow (Purina, Turkey) and tap water ad libitum.

Experimental protocol

Ten and 34-week-old male Sprague-Dawley rats were anesthetized by ether inhalation. The thoracic aorta was quickly removed and placed in oxygenated and cold Krebs solution $\left(95 \% \mathrm{O}_{2}\right.$ and $5 \% \mathrm{CO}_{2}, \mathrm{pH} 7.40$ ) containing (in $\mathrm{mmol} / \mathrm{L}$ ): $\mathrm{NaCl} 118, \mathrm{NaHCO}_{3} 25, \mathrm{KCl} 4.7, \mathrm{KH}_{2} \mathrm{PO}_{4} 1.2, \mathrm{MgSO}_{4} 1.2, \mathrm{CaCl}_{2} 2.50$ and glucose 11. Thoracic aorta was cleaned of all fat and connective tissue and aortic rings were prepared as 3-4 mm length. The rings were mounted between two hooks attached to an isometric force transducer connected to a data acquisition system (Biopac, MP30, CA, USA) for continuous recording of tension. The preparations were suspended in $10-\mathrm{ml}$ tissue baths containing oxygenated Krebs solution at $37^{\circ} \mathrm{C}$. After mounting the aortic rings, the resting tension was increased stepwise to reach a final value of $2000 \mathrm{mg}$. Following one-hour equilibration period, the vessels were contracted by $\mathrm{KCl}(60 \mathrm{mM})$ twice to ensure contractile integrity of all aortic rings.

Assessment of EDCF-mediated responses

It has been demonstrated that in aorta preparations with endothelium, the A23187-mediated contractile responses at the 10nM-10uM concentration range can be evaluated as EDCF responses in the presence of nitric oxide synthase inhibitor $\mathrm{N} \omega$-nitro-L-arginine methyl ester (L-NAME, 100uM, $30 \mathrm{~min}$ ) $(9,12,13)$. A23187-mediated contractile response at the concentration of $10 \mathrm{uM}$ was normalized to $\mathrm{KCl}$ contraction response at $60 \mathrm{mM}$. The ratio of A23187-to- $\mathrm{KCl}$-mediated contraction responses is referred as EDCF response for a given preparation. The effect of aging on EDCF-mediated responses in rat thoracic aorta preparations are evaluated as the difference in A23187mediated contractions between 10- and 34-week-old rats.

In separate protocols, repeated A23187-induced responses were also obtained in vessels from 34-week-old rats, which were exposed to high glucose concentration ( $25 \mathrm{mM}$ glucose in Krebs solution, 14) for two different incubation durations ( 3 and 6 hours, 15) and vessels were kept in this high glucose condition during the repeated administration of A23187. To compare the EDCF responses of preparations at both normoglycemic and hyperglycemic conditions, all preparations were washed every 15 minutes during incubation and at the end of duration cumulative A23187-mediated responses were performed. For osmotic control, aortic rings were also kept in Krebs solution containing $14 \mathrm{mM}$ mannitol in addition to normoglycemic concentration of glucose ( $11 \mathrm{mM}$ glucose $+14 \mathrm{~mm}$ mannitol) for 3 hours.

\section{Reagents}

L-NAME and the calcium ionophore A23187 were purchased from SigmaAldrich (St Louis, MO, USA). The stock solution of L-NAME was prepared in distilled water and stored at $-20^{\circ} \mathrm{C}$. A23187 was dissolved in DMSO at $100 \mathrm{mM}$ and stored at $-20^{\circ} \mathrm{C}$ as aliquots in tightly sealed vials. The dilutions of A23187 were prepared with distilled water and used on the same day for organ bath studies. The DMSO/water ratio applied to the aortic rings with the highest concentration of A23187 was $1 / 10000$.

Statistical analysis:

All values are expressed as mean \pm SEM. The statistical analyses were performed using Student-t-test. $\mathrm{P}<0.05$ was considered statistically significant.

\section{RESULTS}

The contractile responses which are expressed as the percentage of $\mathrm{KCl}$ $(60 \mathrm{mM})$ is found significantly increased in 34-week-old rats compared to 10 week-old one as expected (Figure 1) $\left(E_{\max }, 34\right.$-week vs 10 -week, $14,41 \pm 0,81 \%$ vs $8,61 \pm 1,74 \%, p<0,05)$. For following experiments, A23187-mediated contractile responses were obtained from aortic rings prepared from 34 week-old rats and the $E_{\max }$ value of A23187-mediated contractile response of 34 -week-old rats $(14,41 \pm 0,81 \%)$ was referred as control indicating normoglycemic conditions without any incubation period.

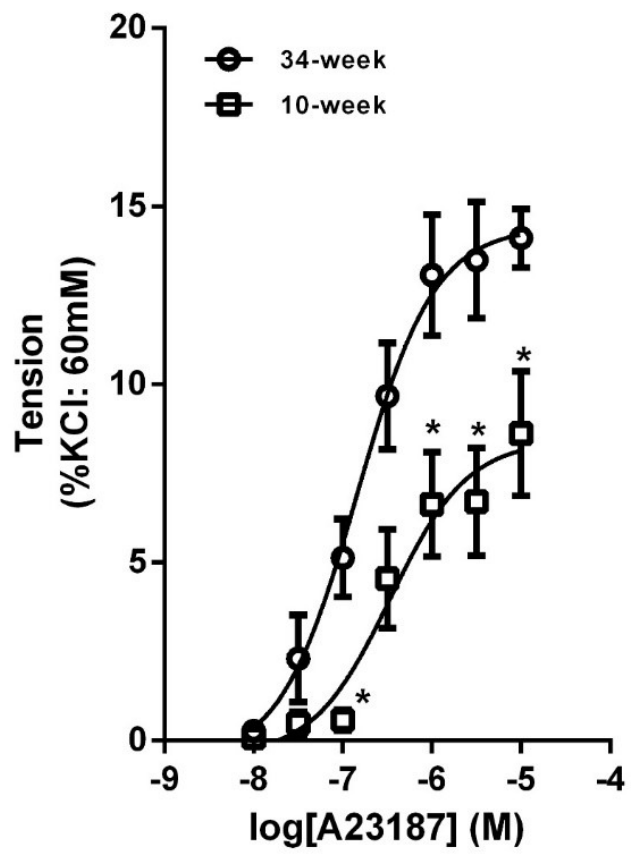

Figure 1: The effect of aging on A23187-mediated contractile responses in rat thoracic aorta. The contractile responses of $A 23187$ were expressed as percentage of $\mathrm{KCl}(60 \mathrm{mM}) . \mathrm{n}=5$ for 10 -week; $\mathrm{n}=8$ for 34 -week. *, $\mathrm{p}<0.05$ vs 34 week.

In normoglycemic conditions $(11 \mathrm{mM})$, the concentration-dependent contractile response induced by $A 23187$ (10nM-10uM) found to be significantly depressed as the incubation period was extended. The $E_{\max }$ value of A23187 concentration-response curve was reduced to $3,51 \pm 1,20 \%$ from $14,41 \pm 0,81 \%$ after 3 hours of incubation in normoglycemic conditions (Figure 2A). In addition, the A23187-mediated contraction was totally abolished after 6 hours of incubation in the presence of same glucose concentration (11mM) (Figure 2A).

The A23187-mediated contractility which was affected from incubation period in a negative manner in normoglycemic conditions improved in response to exposure to high glucose concentration $(25 \mathrm{mM})$ for 3 hours (Figure 2B). The $E_{\max }$ values of A23187 concentration-response curves found statistically insignificant between normoglycemic conditions without any periods (NG) and hyperglycemic conditions after 3 hours of incubation (HG$3 h$ ) ( $E_{\max }, N G$ vs HG-3h, $14,41 \pm 0,81 \%$ vs $\left.17,22 \pm 2,63 \%, p>0,05\right)$ (Figure $2 B$ ). The possible effects of osmotic changes induced by high glucose concentration were checked with mannitol (14mM mannitol+11mM glucose) and no significant differences of $E_{\max }$ was found between rings incubated in mannitol and those in normoglycemic conditions for 3 hours (Figure 2B). 
A

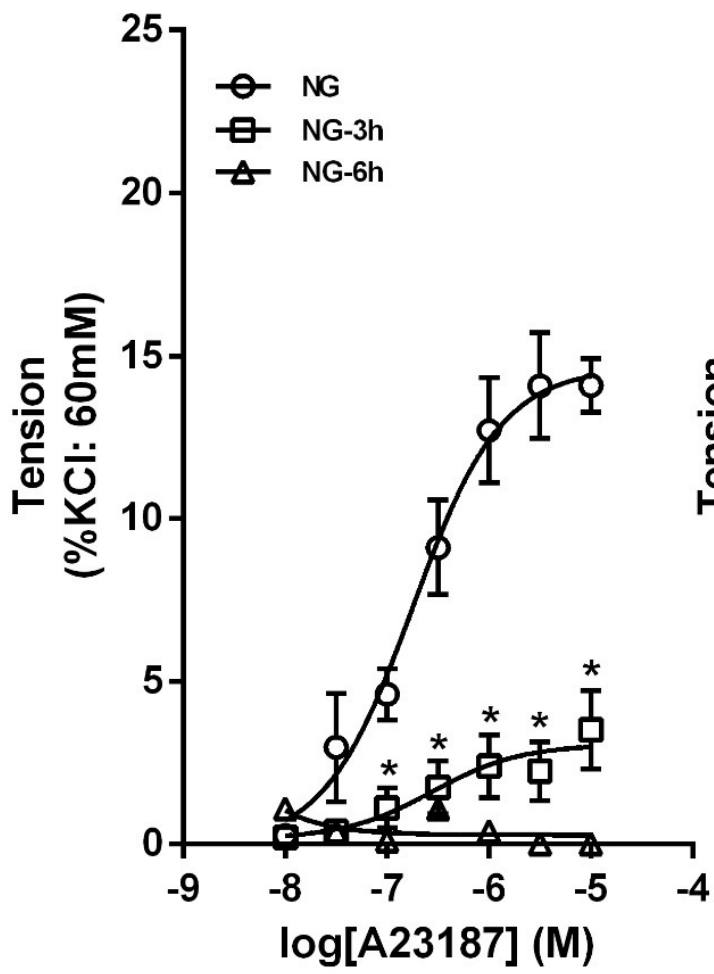

B

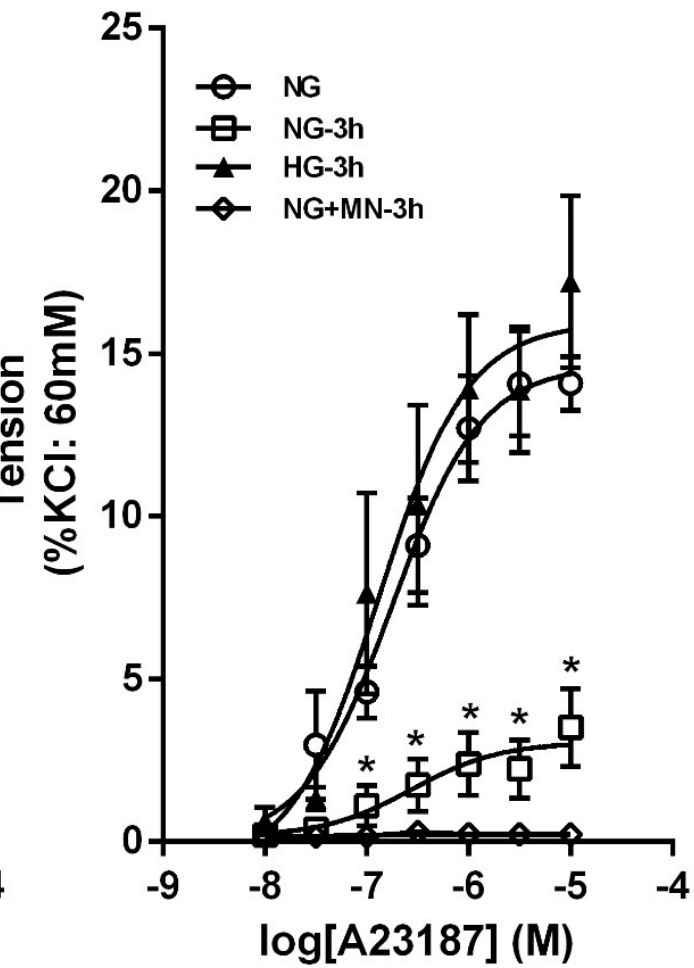

Figure 2. The effects of duration and glucose concentration of in vitro incubation protocols on A23187-mediated contractile responses in thoracic aorta prepared from 34-week-old rats. (A) The effect of incubation time on A23187-mediated contractile responses in normoglycemic conditions. (B) The effect of glucose concentrations on A23187-mediated contractile responses in a single time point (3h). The contractile responses of $\mathrm{A} 23187 \mathrm{were}$ expressed as percentage of $\mathrm{KCl}$ ( $60 \mathrm{mM}$ ). $\mathrm{NG}$ normoglycemia ( $11 \mathrm{mM}$ glucose; $n=5)$, NG-3h: normoglycemia with 3 hours of incubation (11mM glucose; $n=4)$, NG-6h: normoglycemia with 6 hours of incubation (11mM glucose; $n=4)$; HG: hyperglycemia ( $25 \mathrm{mM}$ glucose; $n=5), \mathrm{NG}+\mathrm{MN}$ : normoglycemia plus mannitol (11mM glucose+14mM mannitol; $n=2)$ * , $p<0.05$ vs NG.

\section{DISCUSSION}

The novel finding of the present study is that in vitro high glucose incubation leads to an enhanced constriction in response to $\mathrm{A} 23187$ in rat thoracic aorta. The calcium ionophore A23187 is an agent that faciliates calcium entrance across the membrane without any receptor interaction. Soluble vasoactive factors derived from vascular endothelium modulate the tonus of vascular smooth muscle. Stimulation of intact vessels with acetylcholine causes vasodilatation by release of NO and EDHFs (9). It has been also reported that endothelium can generate vasoconstrictor signals called $\operatorname{EDCF}(16,17)$. Cyclooxygenase- (COX) and endothelium-dependent contractions have been detected in arteries and veins of different species in response to various agents that increase the endothelial intracellular calcium concentrations in a receptor-independent manner as well as in response to physical stimuli such as stretch $(7,8,18-20)$. The calcium ionophore $A 23187$ is an agent that stimulates calcium-dependent endothelial factors $(7,8)$ and it has been preferred to elicit receptor-independent but endothelium-dependent contractions of rat aorta in the presence of NOS inbition (20). As indicated, in the presence of L-NAME incubation, the A23187 mediates contraction in a concentration-dependent manner in thoracic aorta independent from the age of rats used. However, the age of the rats is an important factor for evaluation of the A23187-mediated contractility. Previous studies demonstrated that the EDCF responses has been increased by aging like several pathologies $(6,11$, $21,22)$. It has been showed that the EDCF responses were found to be exaggerated in 54-week-old (14-month) Wistar-Kyoto rats compared to 28week-old (7-month) ones (23). In the current study, the contractile component of endothelium is found to be increased significantly in 34-week-old Spraguedawley rats compared to 10 -week-old ones. The lack of evaluation of endothelium-dependent relaxations in different ages is a limitation of the present study, but whatever the possible reason can be, it is clear that A23187mediated vasocontriction has been exaggerated by aging.

It is more likely that the occurrence of endothelium-dependent contractions is pathological, as they are so prominent in arteries of hypertensive and diabetic animals (11). It has been showed that the endothelium may contribute to the autoregulation of cerebral blood flow during increases in transmural pressure by the increased production and release of prostaglandins, which causes activation of the underlying vascular smooth muscle (19). The abolishment of A23187-mediated contractile responses in a time-dependent manner is a striking result of present study. In normoglycemic conditions, the negative relationship between the extend of exposure period and A23187-mediated contractile responses indicates the detrimental effect of incubation period with extracellular solution on isolated aortae.

Acetylcholine activates muscarinic receptors on the endothelial cell membranes leading to an increase intracellular concentration of calcium. The elevation of endothelial calcium concentration induced by acetylcholine or calcium ionophore A23187 trigger two signaling pathways which have opposite effects on vascular smooth muscle contractility: the activation of endothelial NOS and production of EDCF by COX activation. COX-mediated products like endoperoxides easily diffuse from endothelium to vascular smooth muscle and mediate contraction by TP-receptor activation. The mechanisms which can be responsible from the reduced A23817-mediated contractility in response to exposure period as presented in the current study may be the inhibition of endothelial COX activation and/or hyporesponsiveness of TP-receptors located on vascular smooth muscle. According to the best of our knowledge, there is no data for inhibition of COX activation by exposure periods and/or extracellular conditions in normoglycemic conditions. However, it has been demonstrated that endothelium-dependent contractions to acetylcholine are $\mathrm{pH}$-dependent unlike endothelium-dependent acetylcholine-induced relaxations (24). The endothelium-dependent contractions are found to be increased in alkaline $(\mathrm{pH}$ 7.8) than the control solution $(\mathrm{pH} \mathrm{7.4)}$ and the contractions induced by acetylcholine is depressed at acidic conditions $(\mathrm{pH} 7)$. It has been also shown that the $\mathrm{pH}$ changes have no effect on the release of EDCF, however alterations in the extracellular $\mathrm{pH}$ affect the responsiveness of TP receptors on vascular smooth muscle (24). The results of the mentioned study are quite exciting because the authors showed that $\mathrm{pH}$ of the extracellular solution affects only TP receptor responsiveness without any alteration in endothelium signaling which can the case for the present data. In our experimental settings, the formulation and oxygenation protocol of the extracellular solution was validated according to the $\mathrm{pH} 7.4$. 
Unfortunately, the $\mathrm{pH}$ of the solution in the organ baths did not checked regularly during the whole experimental protocol. The extent of the incubation period could induce an imbalance in the $\mathrm{pH}$ equilibration of extracellular solution. The reduction of the A23187-mediated contractile responses which enhance with the extent of exposure period ( 3 hours vs 6 hours, Figure 2A) in normoglycemic condition may indicate the timedependency of possible alterations on $\mathrm{pH}$ of the extracellular solution.

Endothelium-dependent contractions are also frequently associated with cardiovascular complications. These responses antagonize physiologically the endothelium-dependent vasodilatations produced by NO and/or EDHF and contribute to endothelial dysfunction $(11,13)$. Hyperglycaemia has been shown to induce a variety of acute systemic vascular effects. Proposed mechanisms of vascular dysfunction from acute hyperglycemia include an increased oxidative stress from ROS and a decreased endothelial NO production. Prolonged exposure to high glucose in vitro or in vivo stimulates the overproduction of ROS (25) and destroys the nitric oxide-induced vasodilatation (26). It has been indicated that ROS activation mediates EDCF release in endothelial cells (8). Free radicals have a capable of diffusing from endothelium to vascular smooth muscle and activate TP receptors with prostanoids which are synthesized by ROS-mediated COX activation (27). ROS can also amplify rather than directly induce endothelium-dependent contractions (28). In the present study, enhanced A23187-mediated contractile responses induced by acute hyperglycemia incubation may indicate the acute production and/or activation of ROS in rat aorta. The detrimental effects of hyperglycemia on endothelial function can be seen earlier especially on small arteries like renal artery (29) and coronary artery (30). These small vessels are much more sensitive to ROS activation and endothelial dysfunction induced by hyperglycemia. An in vitro rat study demonstrated decreased arteriolar NO production in response to acetylcholine during hyperglycemia but no difference in vasodilation suggesting increased sensitivity to NO-induced vasodilation (31).

In summary, the results of the present study demonstrated that acute hyperglycemia causes enhanced A23187-mediated contractions of rat thoracic aorta in the presence of NOS inhibition. In normoglycemic conditions, the in vitro incubation of preparations reduced the A23187-induced conractile responses. Therefore, the nature of A23187-mediated contractile responses is likely sensitive to any alteration in physiological conditions, however the hyperglycemia enhanced the A23187-mediated contractility probably through ROS activation.

\section{Acknowledgements}

This study was supported by TUBITAK (115S995).

\section{Conflict of interest}

No conflict of interest was declared by the author.

\section{REFERENCES}

1. Giacco F, Brownlee M. Oxidative Stress and Diabetic Complications. Circ Res 2010; 107: 1058-70.

2. Brownlee M. The Pathobiology of Diabetic Complications: a Unifying Mechanism. Diabetes 2005; 54: 1615-25.

3. Feletou $M$, Vanhoutte PM. Endothelial dysfunction: a multifaceted disorder. Am J Physiol Heart Circ Physiol 2006; 291: H985-1002.

4. Matsumoto $T$, Kobayashi $T$, Kamata K. A therapeutic target for microvascular complications in diabetes: endothelium-derived hyperpolarizing factor. Curr Cardiol Rev 2006; 2: 185-91.

5. Boulanger $\mathrm{CM}$, Morrison KJ, Vanhoutte PM. Mediation by M3-muscarinic receptors of both endothelium-dependent contraction and relaxation to acetylcholine in the aorta of the spontaneously hypertensive rat. $\mathrm{Br} \mathrm{J}$ Pharmacol. 1994; 112:519-24.

6. Koga T, Takata Y, Kobayashi K, Takishita S, Yamashita Y, Fujishima M. Age and hypertension promote endothelium-dependent contractions to acetylcholine in the aorta of the rat. Hypertension 1989; 14: 542-54.

7. Katusic ZS, Shepherd JT, Vanhoutte PM. Endothelium-dependent contractions to calcium ionophore A23187, arachidonic acid, and acetylcholine in canine basilar arteries. Stroke 1988; 19: 476-9.

8. Tang EH, Leung FP, Huang $Y$, Félétou M, So KF, Man RY et al. Calcium and reactive oxygen species increase in endothelial cells in response to releasers of endothelium-derived contracting factor. $\mathrm{Br} J$ Pharmacol 2007; 151: 15-23.

9. Vanhoutte PM, Tang EHC. Endothelium-dependent contractions: when a good guy turns bad!. J Physiol. 2008; 586: 5295-304.

10. Ellinsworth DC, Shukla N, Fleming I, Jeremy JY. Interactions between thromboxane A2, thromboxane/prostaglandin (TP) receptors and endothelium-derived hyperpolarization. Cardiovasc Res 2014; 102: 9-16.

11. Vanhoutte $P M$, Feletou $M$, Taddei $S$. Endothelium-dependent conractions in hypertension. Br J Pharmacol 2005; 144: 449-58.
12. Qu C, Leung SWS, Vanhoutte PM, Man RYK. Chronic Inhibition of NitricOxide Synthase Potentiates Endothelium-Dependent Contractions in the Rat Aorta by Augmenting the Expression of Cyclooxygenase-2. J Pharmacol Exp Ther 2010; 334: 373-80.

13. Feletou $\mathrm{M}$, Verbeuren $\mathrm{Tj}$, Vanhoutte PM. Endothelium-dependent contractions in SHR: a tale of prostanoid TP and IP receptors. $\mathrm{Br} J$ Pharmacol 2009; 156: 563-74.

14. Bagi Z, Feher A, Casutto J, Akula K, Labinskyy N, Kaley G et al. Increased availability of angiotensin AT1 receptors leads to sustained arterial constriction to angiotensin II in diabetes role for Rho-kinase activation. Br J Pharmacol 2010; 163: 1059-68.

15. Tesfamariam B, Brown Ml, Deykın D, Cohen RA. Elevated Glucose Promotes Generation of Endothelium-derived Vasoconstrictor Prostanoids in Rabbit Aorta. J Clin Invest 1990; 85: 929-32.

16. De Mey JG, Vanhoutte PM. Heterogeneous behavior of the canine arterial and venous wall. Importance of the endothelium. Circ Res 1982; 51: 439-47.

17. De Mey JG, Vanhoutte PM. Control of vascular smooth muscle function by the endothelial cells. Gen Pharmacol 1983; 14: 39-41.

18. Miller VM, Vanhoutte PM. Endothelium-dependent contractions to arachidonic acid is mediated by products of cyclooxygenase. Am J Physiol 1985; 248: H432-7.

19. Katusic ZS, Shepherd JT, Vanhoutte PM. Endothelium-dependent contraction to stretch in canine basilar arteries. Am J Physiol 1987; 252: H671-3.

20. Yang $D$, Gluais $P$, Zhang $J N$, Vanhoutte $P M$, Feletou $M$. Endothelium dependent contractions to acetylcholine, ATP and the calcium ionophore A23187 in aortas from spontaneously hypertensive and normotensive rats. Fundam Clin Pharmacol 2004; 18: 321-6.

21. Iwama $Y$, Kato T, Muramatsu M, Asano H, Shimizu K, Toki Y, Miyazaki Y, Okumura K, Hashimoto $\mathrm{H}$, Ito T. Correlation with blood pressure of the acetylcholine-induced endothelium-derived contracting factor in the rat aorta. Hypertension 1992; 19: 326-32.

22. Watt $\mathrm{PA}$, Thurston $\mathrm{H}$. Endothelium-dependent relaxation in resistance vessels from the spontaneously hypertensive rats. J Hypertens. 1989; 7: 661-6.

23. Lišková $S$, Petrová $M$, Karen $P$, Kuneš J, Zicha J. Effects of aging and hypertension on the participation of endothelium-derived constricting factor (EDCF) in norepinephrine-induced contraction of rat femoral artery. Eur J Pharmacol 2011; 667: 265-70.

24. Baretella $\mathrm{O}, \mathrm{Xu} \mathrm{A}$, Vanhoutte PM. Acidosis prevents and alkalosis augments endothelium-dependent contractions in mousearteries. Pflugers Arch. 2014; 466: 295-305.

25. Rodriguez-Manas L, Angulo J, Vallejo S, Peiro C, Sanchez-Ferrer A,Cercas $\mathrm{E}$, et al. Early and intermediate Amadori glycosylation adducts, oxidative stress, and endothelial dysfunction in the streptozotocin-induced diabetic rats vasculature. Diabetologia 2003; 46: 556-66.

26. Qian LB, Wang HP, Chen Y, Chen FX, Ma YY, Bruce LC, Xia Q. Luteolin reduces high glucose-mediated impairment of endothelium-dependent relaxation in rat aorta by reducing oxidative stress. Pharmacol Res 2010; 61: 281-7.

27. Shi $Y$, Vanhoutte PM. Oxidative stress and COX cause hyperresponsiveness in vascular smooth muscle of the femoral artery from diabetic rats. Br J Pharmacol 2008; 154: 639-51.

28. Vanhoutte PM, Shimokawa H, Feletou M, Tang EH. Endothelial dysfunction and vascular disease - a 30th anniversary update. Acta Physiol (Oxf.) 2017; 219: 22-96.

29. Affonso FDS, Cailleaux S, Pinto LFC, Gomes MDB, Tibirica E. Effects of high glucose concentrations on the endothelial function of the renal microcirculation of rabbits. Arq Bras Cardiol 2003; 81: 161-5.

30. Gross ER, Ladisa JF, Jr., Weihrauch D, Olson LE, Kress TT, Hettrick DA, Pagel PS, Warltier DC, Kersten JR. Reactive oxygen species modulate coronary wall shear stress and endothelial function during hyperglycemia. Am J Physiol Heart Circ Physiol 2003; 284: H1552-9.

31. Lash JM, Nase GP, Bohlen HG. Acute hyperglycemia depresses arteriolar NO formation in skeletal muscle. Am J Physiol 1999; 277: H1513-20. 